\title{
Diagnosis and Management of Grain-Induced Asthma
}

\author{
Santiago Quirce, ${ }^{1 *}$ Araceli Diaz-Perales ${ }^{2}$ \\ 'Department of Allergy, Hospital La Paz Institute for Health Research (IdiPAZ) and CIBER of Respiratory Diseases (CIBERES), Madrid, Spain \\ ${ }^{2}$ Centro de Biotecnología y Genómica de Plantas (UPM-INIA), Pozuelo de Alarcón, Madrid, Spain
}

This is an Open Access article distributed under the terms of the Creative Commons Attribution Non-Commercial License (http://creativecommons.org/licenses/by-nc/3.0/) which permits unrestricted non-commercial use, distribution, and reproduction in any medium, provided the original work is properly cited.

Grain-induced asthma is a frequent occupational allergic disease mainly caused by inhalation of cereal flour or powder. The main professions affected are bakers, confectioners, pastry factory workers, millers, farmers, and cereal handlers. This disorder is usually due to an lgE-mediated allergic response to inhalation of cereal flour proteins. The major causative allergens of grain-related asthma are proteins derived from wheat, rye and barley flour, although baking additives, such as fungal $\alpha$-amylase are also important. This review deals with the current diagnosis and treatment of grain-induced asthma, emphasizing the role of cereal allergens as molecular tools to enhance diagnosis and management of this disorder. Asthma-like symptoms caused by endotoxin exposure among grain workers are beyond the scope of this review. Progress is being made in the characterization of grain and bakery allergens, particularly cereal-derived allergens, as well as in the standardization of allergy tests. Salt-soluble proteins (albumins plus globulins), particularly members of the $\alpha$-amylase/trypsin inhibitor family, thioredoxins, peroxidase, lipid transfer protein and other soluble enzymes show the strongest lgE reactivities in wheat flour. In addition, prolamins (not extractable by salt solutions) have also been claimed as potential allergens. However, the large variability of IgE-binding patterns of cereal proteins among patients with grain-induced asthma, together with the great differences in the concentrations of potential allergens observed in commercial cereal extracts used for diagnosis, highlight the necessity to standardize and improve the diagnostic tools. Removal from exposure to the offending agents is the cornerstone of the management of grain-induced asthma. The availability of purified allergens should be very helpful for a more refined diagnosis, and new immunomodulatory treatments, including allergen immunotherapy and biological drugs, should aid in the management of patients with this disorder.

Key Words: Baker's asthma; cereals; wheat allergens; soya flour; fungal enzymes; allergen immunotherapy

\section{INTRODUCTION}

Asthma caused by allergy to proteins from cereal grains is one of the most common types of occupational asthma (OA) and its prevalence does not seem to be declining. ${ }^{1}$ The main professions affected are: bakers, confectioners, pastry factory workers, millers, farmers, and cereal handlers. Although wheat is the most commonly involved cereal, other grains (e.g. rye, barley, rice) also play a role. In addition, flour from other sources (e.g. soya, lupin), pests, and several flour additives used in the baking industry to improve fermentation and elasticity of the dough, as well as to improve storage of the bread, may also give rise to IgEmediated allergy.

\section{EPIDEMIOLOGY}

Work-related respiratory symptoms are highly prevalent among bakery workers, about $5 \%-10 \%$ suffer asthma and $15 \%-20 \%$ rhinitis. Baker's asthma is the most frequent type of OA in France. ${ }^{2}$ Exposure to grain and flour dust is the second commonest re- ported cause of OA in the $\mathrm{UK}^{3}$ and Norway. ${ }^{4}$ The estimated annual incidence of cereal-induced asthma in the UK was 811 cases per million people employed over the period 1989-1997,3 whereas in Norway, the incidence of OA among male and female bakers was 2.4 and 1 case per 1,000 person-years, respectively. ${ }^{4}$ The incidence of baker's asthma among young bakers has been reported to range from 0.3 to 2.4 cases per 1,000 person-years. ${ }^{5}$ In the last years an increasing number of asthma cases is being reported among supermarket bakery workers. ${ }^{6}$

In a prospective study carried out in Québec among apprentice bakers/pastry makers the incidence of work-related sensitization was $4.2 \%$ (per person-year) when the mean duration of follow up was lower than 4 years, ${ }^{7}$ but it was 1.0 for a longer period (8 years) of follow up. ${ }^{8}$

Correspondence to: Santiago Quirce, MD, PhD, Department of Allergy, Hospital La Paz, Paseo de La Castellana, 261, 28046 Madrid, Spain. Tel: +34-91-727-70-80; Fax: +34-91-727-70-50; E-mail: squirce@gmail.com Received: January 2, 2013; Accepted: January 29, 2013

- There are no financial or other issues that might lead to conflict of interest. 


\section{PATHOGENESIS AND RISK FACTORS}

This disorder has been classically considered a form of allergic asthma mediated by IgE antibodies specific to cereal flour antigens, mainly wheat, rye and barley, ${ }^{9}$ but other cereal grains, such as rice, have also been implicated in cereal-induced asthma and rhinitis. ${ }^{10,11}$ However, baking and food technology has notably progressed in the last decades and a vast array of biologic and chemical additives are now commonly used. Thus, it is not surprising that the list of causative agents of baker's asthma has been expanded with the demonstration that flours from different sources (soybean, buckwheat, and lupin), enzymes, egg proteins and organic contaminants such as storage mites, moulds and insects are also capable of causing IgE-mediated $\mathrm{OA}^{12}$ (Table 1).

In a study in a Korean bakery, the overall prevalence of wheat

Table 1. Allergenic sources described in grain/flour-induced asthma

\begin{tabular}{|c|c|c|}
\hline & Scientific name & Reference \\
\hline \multicolumn{3}{|l|}{ Cereal flour/dust } \\
\hline Wheat & Triticum aestivum & 9,12 \\
\hline Rye & Secale cereale & 9,23 \\
\hline Barley & Hordeum vulgare & 9,12 \\
\hline Rice & Oryza sativa & $10,11,65$ \\
\hline \multicolumn{3}{|l|}{ Fungal enzymes } \\
\hline Alpha-amylase & Aspergillus oryzae (Asp o 21) & 76,78 \\
\hline Hemicellulase/cellulase & Aspergillus niger & 77,78 \\
\hline Glucoamylase & Aspergillus niger & 79 \\
\hline Beta-xyloxidase & Aspergillus niger(Asp n 14) & 77 \\
\hline Xylanase & Aspergillus niger & 80 \\
\hline \multicolumn{3}{|l|}{ Legumes } \\
\hline Soya flour & Glycine max & 81,82 \\
\hline Soybean lecithin & Glycine max & 83 \\
\hline Lupin flour & Lupinus albus & 84 \\
\hline Baker's yeast & Saccharomyces cerevisiae & 85 \\
\hline \multicolumn{3}{|l|}{ Other ingredients } \\
\hline Buckwheat flour & Fagopyrum esculentum & 86 \\
\hline Sunflower seeds & Helianthus annuus & 87 \\
\hline Egg white proteins & Gal d 1, Gal d 2, Gal d 3, Gal d 4 & 88 \\
\hline \multirow[t]{4}{*}{ Storage mites } & & 89,90 \\
\hline & Lepidoglyphus destructor & \\
\hline & Acarus siro & \\
\hline & Tyrophagus putrescentiae & \\
\hline \multicolumn{3}{|l|}{ Arthropods } \\
\hline Grain weevil & Sitophilus granarius & 91 \\
\hline Flour moths & Ephestia spp. and Eurigaster spp. & 92 \\
\hline Spider & Holocnemus pluchei & 93 \\
\hline \multirow[t]{3}{*}{ Molds } & & 94 \\
\hline & Aspergillus fumigatus & \\
\hline & Alternaria alternata & \\
\hline
\end{tabular}

sensitization was $5.9 \%$, and it was confirmed that an IgE-mediated response is the major pathogenic mechanism for the induction of work-related symptoms in wheat-exposed workers, whereas wheat-specific IgG antibodies may represent current or previous exposure to wheat dust. ${ }^{13}$

Moreover, workers handling cereal or vegetable seeds are at risk of exposure to high levels of endotoxin containing seed dust. Occupational exposure to inhalable agricultural seed dust can induce inflammatory responses, and is a potential cause of organic dust toxic syndrome (ODTS), which typically presents with asthma-like symptoms, and is an important differential diagnosis of OA. ${ }^{14}$ Moreover, exposure to flour allergens and endotoxins interact to induce allergic responses and respiratory symptoms. Grain dust-related asthma symptoms caused by exposure to endotoxins, which have been reported among agricultural and grain elevator workers, are not addressed in this review.

Houba et al. ${ }^{15}$ investigated the relationship between allergen exposure and IgE sensitization to wheat flour among bakery workers. A strong and positive association was found between wheat flour allergen exposure and wheat flour sensitization, for both atopic and non-atopic workers, and this relationship was steepest within the group of atopic bakers. This means that the likelihood of sensitization increased with increasing wheat allergen concentration in the workplace air, and the risk was higher for atopic subjects.

Several studies have shown that the level of exposure and atopy are the main risk factors for developing sensitization and work-related symptoms among subjects exposed to cereal flour. Age, gender, and smoking habits do not seem to be associated with sensitization or work-related respiratory symptoms. ${ }^{12} \mathrm{~A}$ study carried out in Belgium compared bakery workers with a nonexposed work population and showed that atopy and sensitization to bakery allergens were independent and additional risk factors for work-related symptoms. ${ }^{16}$

Genetic factors seem to be also important in the development of work-related respiratory symptoms and sensitization to wheat flour in bakery workers. In this regard, Cho et al. ${ }^{17}$ carried out a study in Korean bakery workers, and they found that Toll-like receptor 4 (TLR4) gene polymorphisms may be involved in allergic sensitization to wheat flour as well as endotoxin-induced respiratory symptoms in endotoxin-allergen-exposed workers and that carriers of TLR4 variants are less affected by environmental exposure. In a study in Korean bakery workers, Hur et al. ${ }^{18}$ reported that the genetic polymorphisms of $\beta 2$-adrenergic receptors (ADRB2) may contribute to the development of workrelated symptoms in workers exposed to wheat flour, which can lead to baker's asthma.

\section{DIAGNOSIS}

The diagnosis of grain-induced asthma depends on a consis- 
tent history of work-related asthma symptoms, assessment of IgE-mediated sensitization (by means of skin prick tests or in vitro tests) to cereal proteins or other bakery allergens, and evidence of variability in lung function. The diagnosis can be confirmed by specific inhalation challenge (SIC) with bakery allergens.

In epidemiological studies the diagnosis of OA is usually performed using a combination of symptoms and bronchial hyperresponsiveness (BHR) to pharmacological agents (usually methacholine or histamine), while in the clinical setting the 'gold standard' for the diagnosis of OA is the SIC test in the laboratory. However, a step-by-step approach has also been proposed for cross-sectional epidemiological studies in workers exposed to grain and/or flour dust. ${ }^{19}$ BHR was observed in a small percentage of subjects with asthma-like symptoms and/ or low FEV1, and a positive response to SIC to wheat flour was observed in a subgroup of subjects with BHR, stressing the need to perform SIC to confirm the diagnosis of flour-induced OA. ${ }^{19}$

Rhinitis, with or without conjunctivitis, is commonly associated with flour-induced asthma, and should also be considered in the diagnosis and management.

\section{Skin prick tests}

The frequency of sensitization to wheat flour by SPT among cereal workers in epidemiological studies varies from $5 \%$ to $15 \% .{ }^{12}$ Skin reactivity is related to the quality, potency and standardization of allergen extracts, which are often poorly defined for cereal and other occupational allergens. Sander et al. ${ }^{20}$ carried out a study to compare different wheat and rye flour extracts used for skin testing, and related the results to the outcome of SIC as gold standard. Wheat and rye flour extracts for SPT from three companies differed in protein concentrations and composition, resulting in a wide difference in SPT results. Sensitivity of SPTs was between $40 \%$ and $67 \%$, specificity was between $86 \%$ and $100 \%$, the positive predictive value (PPV) ranged from $81 \%$ to $100 \%$ and the negative predictive value (NPV) from $44 \%$ to $70 \% .^{20}$

van Kampen et al. ${ }^{21}$ carried out a multicenter study in which SPT were performed with wheat and rye flour extracts from 4 producers in 125 symptomatic bakers. Comparisons between SPT results of different extracts were made with flour-specific IgE. The optimal cut-off level for all SPT solutions was a weal size of $\geq 1.5 \mathrm{~mm}$. Again, a wide variability of SPT wheat and rye flour extracts from different producers was found. These data indicate that improvement and standardization of SPT solutions used for the diagnosis of cereal-induced asthma are needed.

\section{Specific lgE measurements}

The sensitivity of specific IgE measurements (by either ImmunoCAP or ELISA) has been shown to be higher than SPT with commercial cereal (wheat and rye) extracts. ${ }^{20}$ The sensitivity of specific IgE to wheat and rye flour was $83 \%$ and $72 \%$, respective- ly, whereas the specificity was $59 \%$ and $81 \%$.

\section{Specific inhalation challenge}

SIC is still considered the gold standard for the diagnosis of baker's asthma. ${ }^{22}$ Despite the broad allergenic cross-reactivity between wheat and rye flour, some patients may have a negative SIC with wheat flour and a positive reaction to SIC with rye flour, ${ }^{23}$ indicating that SIC should be performed with flour from different cereals.

van Kampen et al. ${ }^{24}$ evaluated the relevance of flour-specific serum IgE and SPT in the diagnosis of baker's asthma and for the purpose of defining flour-specific IgE concentrations and wheal sizes that make it possible to predict the outcome of SIC. The results of the challenge with wheat flour were positive for 37 bakers, while 63 had positive results with rye flour. Depending on the flour-specific IgE concentrations (wheal size), positive predictive value (PPV) was $74 \%-100 \%$ for wheat and $82 \%$ $100 \%$ for rye flour, respectively. The minimal cutoff values with a PPV of $100 \%$ were $2.32 \mathrm{kU} / \mathrm{L}$ (wheal size $5.0 \mathrm{~mm}$ ) for wheat flour, and $9.64 \mathrm{kU} / \mathrm{L}$ (wheal size $4.5 \mathrm{~mm}$ ) for rye flour. Thus, high concentrations of flour-specific IgE and clear SPT results in symptomatic bakers are good predictors of a positive challenge test result.

These observations suggest that SIC with cereal flours can be avoided in strongly sensitized bakers. In fact, a systematic literature review showed that in workers with suspected OA caused by high-molecular-weight agents, a positive SPT result and BHR to methacholine correlates with SIC (high specificity, moderate sensitivity). ${ }^{25}$

The main determinant of a positive SIC to an allergen in patients with baker's asthma is the degree of sensitization to that allergen as determined by skin reactivity, modulated to a lesser extent by non-specific BHR. ${ }^{26}$

On the other hand, in baker's with persistent cough and a negative asthmatic response to the SIC, a diagnosis of non-asthmatic eosinophilic bronchitis should be considered. Monitoring of airway inflammation by non-invasive methods (induced sputum and/or exhaled nitric oxide) is necessary to confirm the diagnosis. $^{27,28}$

\section{WHEAT GRAIN PROTEINS AND INHALANT ALLERGENS}

Protein represents about $10 \%-15 \%$ (dry weight) of wheat grain. It can be classified in four different fractions based on sequential extraction in a series of solvents. ${ }^{29}$ Salt-soluble fractions, named albumins and globulins, include only $15 \%-20 \%$ of the total protein, whereas most protein components, designated prolamins (gliadins plus glutenins), are not extracted by salt solutions. Gliadins are monomeric proteins, and are grouped into three types, designated $\alpha / \beta$-, $\gamma$ - and $\omega$-gliadins, according to their electrophoretic mobility at low $\mathrm{pH}$ and biochemical characteristics. ${ }^{30}$ Glutenins form polymers maintained by inter- 
chain disulphide bridges, and are classified into high molecular weight (HMW) and low molecular weight (LMW) glutenin subunits. ${ }^{30}$

The sequential extraction procedure does not render clear-cut preparations, as expected. Thus, cross-contamination among protein fractions can occur (i.e. some salt-soluble proteins, such as $\alpha$-amylase inhibitor subunits, can residually appear in the glutenin fraction). ${ }^{31}$ Nevertheless, the peculiar extractability properties of wheat grain proteins lead to several constrain of commercial diagnostic products. Thus, wheat ImmunoCAP contains preponderantly salt-soluble proteins, and has to be complemented with glutenin ImmunoCAP, and/or $\omega-5$ gliadin ImmunoCAP, for proper diagnosis of same patients. ${ }^{32}$

A high degree of heterogeneity of recognized allergens between groups with different clinical profiles (food allergy, wheatdependent exercise induced anaphylaxis -WDEIA-, baker's asthma), as well as within each group, has been reported. ${ }^{33}$ However, mainly salt-soluble proteins seem to be associated with baker's asthma.

The main allergens implicated in cereal-induced asthma are: the $\alpha$-amylase/trypsin inhibitor family, lipid transfer protein (LTP), peroxidase, thioredoxin, serine proteinase inhibitor, thaumatin-like protein and some prolamins.

Besides the above mentioned allergens, additional IgE-binding proteins, such as acyl-CoA oxidase, fructose-bisphosphate aldolase, triosephosphate isomerise, glycerinaldehyde-3-phosphate dehydrogenase, and serpin, has been located by a proteomic approach and IgE-immunodetection. ${ }^{34,35}$ On the other hand, $\beta$-amylase (from barley flour) ${ }^{36}$ and Tri a Bd $27 \mathrm{~K}$, a member of the $\gamma$-interferon-inducible thiol reductases, ${ }^{37}$ have been reported as putative allergens. An association between baker's asthma and allergy to kiwifruit ${ }^{38}$ has been described, suggesting that wheat thiol-proteases homologous to kiwi Act d 1 can be responsible for wheat-kiwi cross-reactivity.

Recently, Pahr et al. ${ }^{39}$ using a cDNA library, have reported the molecular characterization, recombinant expression and purification of five wheat allergens involved in respiratory allergy: 1-Cys-peroxiredoxin, dehydrin, a thioredoxin $\mathrm{h}$ isoform, gluthathione transferase, and profilin.

\section{The cereal $\alpha$-amylase/trypsin inhibitor family}

The $\alpha$-amylase/trypsin inhibitor family is regarded as the major type of wheat allergens responsible for cereal asthma. ${ }^{29,40}$ This family comprises a large proportion of the salt-soluble proteins from wheat flour, including the so-called CM proteins, which besides salt-solutions, can be also extracted with chloroform/methanol mixtures. ${ }^{41}$

The cereal $\alpha$-amylase/trypsin inhibitor subunits are $12-16 \mathrm{kDa}$ polypeptides with 4-5 intrachain disulphide bridges essential for their inhibitory activity. ${ }^{41}$ Members of the inhibitor family are restricted to the seed storage tissue (endosperm) and seem to have a common fold. ${ }^{41,42}$
The inhibitor subunits are encoded by a multigene family in wheat, rye and barley. Thus, up to 12 different subunits have been characterized in a single bread wheat (Triticum aestivum) cultivar, most of them with IgE-binding capacity (see below). ${ }^{40,41}$ Amino acid sequence identity between members of the family ranges from around $30 \%$ to $95 \%$.

Three types of $\alpha$-amylase inhibitors have been identified in wheat flour based on their degree of aggregation: monomeric (1 subunit), homodimeric (2 identical subunits) and heterotetrameric (3 different subunits, one of them in two copies). ${ }^{40,41,43}$

Activity towards heterologous $\alpha$-amylases from insects, mites, mammals and/or bacteria, but not against the endogenous $\alpha$ amylases present in the cereal kernel, has been described for the wheat inhibitors. ${ }^{40,41}$ Their role in plant defence is supported by the negative effects on the amylase activity of coleopteran and lepidopteran pests, mainly predators of stored cereal grains. ${ }^{4,45}$

Extensive data reported by different groups, mainly based on 1- and 2-dimensional immunoblotting of wheat flour salt-soluble proteins, allowed to identify several 12-16 kDa members of the $\alpha$-amylase/trypsin inhibitor family as major IgE-binding proteins in sera from wheat-induced asthmatic patients. ${ }^{34-36,46-51}$ The in vitro analysis of purified inhibitor subunits fully confirmed their IgE-binding capacity. ${ }^{47,49,51,52}$

Biological activity of allergenic wheat $\alpha$-amylase inhibitors was indicated by the induction of histamine release from peripheral basophils by wheat flour fractions enriched in salt-soluble 14 $\mathrm{kDa}$ electrophoretic bands, ${ }^{53}$ and by the stimulation of leukotriene release from peripheral leucocytes by both purified WMAI1 and WDAI-2 allergens. ${ }^{51}$

Armentia et al. ${ }^{54}$ carried out SPT with 6 purified inhibitor subunits from wheat flour, which allowed evaluating the in vivo reactivity of representative members of this allergen family. Most asthmatic patients (87\%) sensitized to wheat flour reacted to a protein preparation enriched in inhibitor subunits, as well as $(80 \%)$ to at least one isolated wheat subunit. However, positive responses to purified inhibitor allergens so far assayed varied from $16 \%$ to $45 \%$, being a glycosylated tetrameric inhibitor subunit (gWTAI-CM16) the highest reactive protein.

Homology among inhibitor subunits from wheat, rye and barley partially accounts for cross-reactivity between flours from these cereals. ${ }^{40,48,50}$ Allergens belonging to the $\alpha$-amylase inhibitor family and associated with baker's asthma have been isolated from rye ${ }^{55,56}$ and barley ${ }^{54,57}$ flour, and their reactivity confirmed by in vivo SPT. ${ }^{54,56}$ Interestingly, three of the rye inhibitors tested, namely Sec c 1, RDAI- 1 and RDAI-3, provoked positive SPT responses in more than $50 \%$ of 21 patients with baker's asthma induced by rye flour.

\section{Peroxidase}

Sanchez-Monge et al..$^{58}$ isolated a prominent IgE-binding protein of $36 \mathrm{kDa}$ from diploid (Triticum monococcum) wheat flour. The protein, which is also present in tetraploid (pasta) and hexa- 
ploid (bread) wheat, was identified as a seed-specific peroxidase harbouring N-linked complex glycans (CCDs). Sera from 6 out of 10 patients with baker's asthma displayed in vitro (dot-blot) reaction to the purified allergen. The biochemical characteristics of the peroxidase were latter confirmed by Yamashita et al., ${ }^{59}$ who suggested IgE-binding to the glycan moiety.

\section{Thioredoxin}

Thioredoxins are $12-14 \mathrm{kDa}$ ubiquitous regulatory proteins that reduce intrachain disulphide bridges of target proteins, such as the wheat storage prolamins (gliadins and glutenins), thus enhancing the mobilization of these storage proteins in germinating wheat seeds. ${ }^{60}$ Wheat thioredoxin, named Tri a 25, has been located as a novel allergen related to cereal-induced asthma by screening of a wheat cDNA phage display library with sera from patients suffering this occupational disease. ${ }^{61}$

Both Tri a 25 and its homologous ( $74 \%$ of amino acid sequence identity) maize thioredoxin Zea $\mathrm{m} 25$ have been produced in $E$. coli as recombinant proteins, and tested against 17 sera from patients with baker's asthma. ${ }^{61}$

\section{Non-specific lipid transfer protein (LTP)}

Plant LTPs constitute a panallergen family of $9 \mathrm{kDa}$ basic polypeptides, which show a 3D-fold characterized by a compact domain composed of $4 \alpha$-helices strongly linked by a network of 4 conserved disulphide bridges. ${ }^{62}$ A main in vivo function of these proteins seems to be their involvement in plant defence mechanisms against phytopathogens (bacteria and fungi), this leading to their classification as pathogenesis-related (PR) proteins (PR-14 family). ${ }^{62}$

Palacin et al. ${ }^{63}$ have characterized wheat flour LTP, named wheat Tri a 14, as a major allergen associated with baker's asthma. Specific IgE to this wheat flour LTP was detected in $60 \%$ of sera from 40 Spanish patients with baker's asthma, and in vivo reactivity (positive SPT response) found in 15 (62\%) out of 24 of these patients. Furthermore, recombinant Tri a 14 has been produced in Pichia pastoris, and its physicochemical properties, heat and proteolytic resistance, and IgE-binding capacity shown almost equivalent to those of its natural counterpart. ${ }^{64}$ These characteristics, together with its biological potency, ${ }^{64}$ makes rTri a 14 a helpful tool for the diagnosis of cereal-induced asthma. Moreover, LTP has also been implicated in rhinitis and asthma caused by rice inhalation. ${ }^{65}$

\section{Serine proteinase inhibitor}

Constantin et al. ${ }^{66}$ identified in 2008 a serine proteinase inhibitor as a novel allergen in baker's asthma, by screening of a cDNA library from wheat seeds with serum IgE from asthmatic patients. The allergen is a $9.9 \mathrm{kDa}$ protein, usually forming $40 \mathrm{kDa}$ tetramers, which represent a new member of the potato inhibitor I family. The inhibitor is mainly expressed in mature seeds, being accumulated in the starchy endosperm and the aleuron layer. It is probably involved in plant defence and belongs to the pathogenesis-related (PR) protein-6 family.

The recombinant form of this allergen produced in E. coli, but not the natural one, has been assayed against sera from baker's asthma patients. ${ }^{66}$ The recombinant allergen reacted with specific IgE from $14 \%^{66}$ and $27 \%^{67}$ sera from Spanish baker's asthma subjects, when tested in dot blotted or micro-arrayed samples, respectively. In contrast, the inhibitor was not recognized by sera from patients suffering wheat food or grass pollen allergy ${ }^{66,67}$ Biological activity of the recombinant allergen was ascertained by 3 out of 3 positive basophil histamine release assays. ${ }^{66}$

Despite around $50 \%$ amino acid sequence identity, no relevant cross-reactivity was found with homologous inhibitors from maize and rice. ${ }^{66}$

\section{Thaumatin-like protein}

Thaumatin-like proteins (TLPs) is the latest salt-soluble protein family from wheat flour that has been associated to baker's respiratory allergy by Lehto et al. ${ }^{68}$ in 2010. Most TLPs have molecular masses ranging from 21 to $26 \mathrm{kDa}$, and 16 conserved cysteine residues forming 8 disulphide bridges that are responsible for a compact 3D-structure and resistance to low $\mathrm{pH}$ conditions, proteolysis and heat treatment. ${ }^{69}$ TLP antifungal activity supports the role of these proteins in plant defence against fungal pathogens and their assignment to form family 5 of the pathogenesis-related (PR) proteins. ${ }^{69}$

Purified wheat TLP induces positive SPT responses in $30 \%$ to $45 \%$ Finnish patients with baker's asthma when tested at $50 \mu \mathrm{g} /$ $\mathrm{mL}$ and $500 \mu \mathrm{g} / \mathrm{mL}$, respectively. ${ }^{68}$

\section{Prolamins: gliadins and glutenins}

Several of the major water/salt-insoluble wheat flour proteins (prolamins) also appear to be implicated in baker's asthma. Several studies ${ }^{70-72}$ have demonstrated IgE-binding in the prolamin fraction, including by $\alpha$-, $\beta$-, $\gamma$ - and $\omega$-gliadins, and LMWglutenin subunits. ${ }^{71}$ However, very few studies have evaluated the allergenicity of purified (recombinant) prolamins. ${ }^{73,74}$ Bittner et $\mathrm{al}^{74}$ expressed in $E$. coli a cDNA encoding an $\alpha \beta$-gliadin of 20 $\mathrm{kDa}$, and isolated the corresponding recombinant prolamin. ELISA screening of 153 sera of bakers with OA using the recombinant $\alpha \beta$-gliadin, detected specific IgE in $12 \%$ of the sera tested. Of the asthmatic bakers, $33 \%$ showed sensitization to natural total gliadin.

\section{OTHER ALLERGENS ASSOCIATED WITH GRAIN INDUCED ASTHMA}

In addition to cereal proteins, a wide array of components, mostly additives used to improve wheat flour quality for baking, such as fungal enzymes (mainly $\alpha$-amylase from Aspergillus oryzae, termed Asp o 21), have been also associated with baker's asthma. $^{75}$ 


\section{Flour improvers}

Starch-cleaving enzymes are well known additives in processing of fermented dough products and are widely used in the baking industry to hasten and economize the bread-making process. By hydrolyzing starch molecules to fermentable sugars, these enzymes continuously generate a substrate that can be used by yeast.

Baur et al. ${ }^{76}$ reported in 1986 the first description of allergy to $\alpha$-amylase from Aspergillus oryzae in baker's asthma. Fungal $\alpha$-amylase is an endoglycosidase which catalyses the hydrolysis of internal alpha-1, 4-glycosidic linkages in various polysaccharides yielding a mixture of maltose and glucose. This enzyme is added to flour (in amounts of milligrams per kg flour) to compensate for the low natural content of amylases of cereal flour and so enhance carbohydrate fermentation by yeast. These authors found that 12 out of 35 (34\%) bakers with asthma had developed IgE-mediated allergy to $\alpha$-amylase. ${ }^{76}$ More recent studies have shown that $23 \%$ of German bakers suffering from workplace-related rhinitis and/or asthma were sensitized to fungal $\alpha$-amylase. ${ }^{77}$

In addition, other fungal enzymes used as baking additives such as hemicellulase, cellulase, xylanase, and glucoamylase (or amyloglucosidase) from Aspergillus niger have been shown to cause IgE-mediated sensitization by means of in vitro and in vivo tests. ${ }^{77-80}$ The frequency of serum specific IgE to glucoamylase among symptomatic bakers varies from $5 \%$ to $8 \%$, indicating that this enzyme may be a relevant allergen in the baking industry. ${ }^{79}$

Soya flour is used as a baking additive for the emulsifying properties of lecithin and the whitening effect of lipoxygenase. The presence of specific IgE antibodies recognizing lipoxygenase and/or soybean trypsin inhibitor have been demonstrated in symptomatic bakers, ${ }^{75,81,82}$ and soybean lecithin has also been reported as a causative agent of $\mathrm{OA} .^{83}$ More recently, cases of rhinitis and asthma caused by lupin flour have been reported but their impact in the bakery sector is not yet established. ${ }^{84}$

Other bakery ingredients that have been implicated in isolated cases of baker's asthma are baker's yeast (Saccharomyces cerevisiae) ${ }^{85}$ buckwheat, ${ }^{86}$ sunflower seed, ${ }^{87}$ and egg proteins. ${ }^{88}$

\section{Grain dust contaminants and pests}

Storage mite (Lepidoglyphus destructor, Acarus siro and Tyrophagus putrescentiae) have been frequently implicated in cereal asthma but their causative role has not been demonstrated beyond doubt. ${ }^{89,90}$ Other insects, ${ }^{91,92}$ spiders ${ }^{93}$ and fungi ${ }^{94}$ that may contaminate grain and/or flour have been incriminated in respiratory allergy, but their role appears to be extremely limited.

\section{MANAGEMENT}

As in other types of immunologic OA, early diagnosis and early avoidance of further exposure are the cornerstones of man- agement for patients with grain-induced asthma. ${ }^{95}$ Whenever feasible the patient should be relocated to a job category without exposure. Pharmacological treatment of OA should comply with published asthma guidelines.

Allergen-specific immunotherapy (SIT) and other biological treatments, such as anti-IgE monoclonal antibodies (omalizumab), also may play a role in management.

Armentia et al. ${ }^{96}$ published the results of the first double-blind placebo-controlled study of SIT with cereal flour in baker's asthma in 1990. Twenty patients were treated with an aqueous wheat flour extract (ALK-Abelló, Madrid, Spain) and 10 with placebo for 10 and 20 months. After SIT, the active group showed a significant decrease in skin sensitivity and also in bronchial hyperresponsiveness to methacholine. Specific IgE to wheat flour decreased only in patients who were treated with SIT for 20 months. Patients in the active group also reported a significant subjective improvement, whereas patients in the placebo group showed no changes in skin sensitivity or BHR to methacholine.

Case reports ${ }^{97}$ and retrospective studies ${ }^{98}$ have also shown efficacy of wheat flour SIT in baker's asthma. An observational cross-sectional retrospective study was performed on 41 sensitised bakers ${ }^{98}$ who underwent subcutaneous SIT with wheat flour extract (Lofarma Allergeni, Milan, Italy) for 4 or more years, without avoiding their work activity. The outcome was investigated after 5 or 10 years. Thirty-four subjects out of 41 were still at work with an acceptable quality of life and a normal working activity, mainly in their small enterprises. In the subgroup of 19 patients treated in the past, several bakers still at work had stopped SIT even from 4-10 years. In the subgroup of 15 patients, still in treatment, symptoms and drug use during the work activity resulted to be reduced or absent in the majority of cases. The authors suggested that SIT with wheat flour may allow relocation in many of cases of baker's asthma and may be associated with other environmental interventions in the workplaces. ${ }^{98}$

Omalizumab has been shown to have clinical benefit in patients with uncontrolled severe baker's asthma. ${ }^{99,100}$

\section{ACKNOWELDGMENTS}

In memoriam of Prof. Gabriel Salcedo, for his outstanding contribution, leadership and teaching on biochemistry and allergen characterization, specifically on plant and cereal allergens.

\section{REFERENCES}

1. Malo JL, Chan-Yeung M. Agents causing occupational asthma. J Allergy Clin Immunol 2009;123:545-50.

2. Ameille J, Pauli G, Calastreng-Crinquand A, Vervloët D, Iwatsubo Y, Popin E, Bayeux-Dunglas MC, Kopferschmitt-Kubler MC; Observatoire National des Asthmes Professionnels. Reported incidence 
of occupational asthma in France, 1996-99: the ONAP programme. Occup Environ Med 2003;60:136-41.

3. McDonald JC, Keynes HL, Meredith SK. Reported incidence of occupational asthma in the United Kingdom, 1989-97. Occup Environ Med 2000;57:823-9.

4. Leira HL, Bratt U, Slåstad S. Notified cases of occupational asthma in Norway: exposure and consequences for health and income. Am J Ind Med 2005;48:359-64.

5. Rémen T, Coevoet V, Acouetey DS, Guéant JL, Guéant-Rodriguez RM, Paris C, Zmirou-Navier D. Early incidence of occupational asthma among young bakers, pastry-makers and hairdressers: design of a retrospective cohort study. BMC Public Health 2010;10: 206.

6. Baatjies R, Lopata AL, Sander I, Raulf-Heimsoth M, Bateman ED, Meijster T, Heederik D, Robins TG, Jeebhay MF. Determinants of asthma phenotypes in supermarket bakery workers. Eur Respir J 2009;34:825-33.

7. Gautrin D, Ghezzo H, Infante-Rivard C, Malo JL. Incidence and determinants of IgE-mediated sensitization in apprentices. A prospective study. Am J Respir Crit Care Med 2000;162:1222-8.

8. Gautrin D, Ghezzo H, Infante-Rivard C, Magnan M, Larchevêque J, Suarthana E, Malo JL. Long-term outcomes in a prospective cohort of apprentices exposed to high-molecular-weight agents. Am J Respir Crit Care Med 2008;177:871-9.

9. Brant A. Baker's asthma. Curr Opin Allergy Clin Immunol 2007;7: 152-5.

10. Kim JH, Choi GS, Kim JE, Ye YM, Park HS. Three cases of rice-induced occupational asthma. Ann Allergy Asthma Immunol 2010; 104:353-4.

11. Kim JH, Kim JE, Choi GS, Hwang EK, An S, Ye YM, Park HS. A case of occupational rhinitis caused by rice powder in the grain industry. Allergy Asthma Immunol Res 2010;2:141-3.

12. Houba R, Doekes G, Heederik D. Occupational respiratory allergy in bakery workers: a review of the literature. Am J Ind Med 1998;34: $529-46$.

13. Hur GY, Koh DH, Kim HA, Park HJ, Ye YM, Kim KS, Park HS. Prevalence of work-related symptoms and serum-specific antibodies to wheat flour in exposed workers in the bakery industry. Respir Med 2008;102:548-55.

14. Smit LA, Wouters IM, Hobo MM, Eduard W, Doekes G, Heederik D. Agricultural seed dust as a potential cause of organic dust toxic syndrome. Occup Environ Med 2006;63:59-67.

15. Houba R, Heederik D, Doekes G. Wheat sensitization and work-related symptoms in the baking industry are preventable. An epidemiologic study. Am J Respir Crit Care Med 1998;158:1499-503.

16. Droste J, Myny K, Van Sprundel M, Kusters E, Bulat P, Braeckman L, Vermeire P, Vanhoorne M. Allergic sensitization, symptoms, and lung function among bakery workers as compared with a nonexposed work population. J Occup Environ Med 2003;45:648-55.

17. Cho HJ, Kim SH, Kim JH, Choi H, Son JK, Hur GY, Park HS. Effect of Toll-like receptor 4 gene polymorphisms on work-related respiratory symptoms and sensitization to wheat flour in bakery workers. Ann Allergy Asthma Immunol 2011;107:57-64.

18. Hur GY, Park HJ, Lee HY, Koh DH, Lee BJ, Choi GS, Kim SH, Ye YM, Park HS. Association of beta(2)-adrenergic receptor polymorphism with work-related symptoms in workers exposed to wheat flour. Yonsei Med J 2011;52:488-94.

19. Talini D, Benvenuti A, Carrara M, Vaghetti E, Martin LB, Paggiaro PL. Diagnosis of flour-induced occupational asthma in a cross- sectional study. Respir Med 2002;96:236-43.

20. Sander I, Merget R, Degens PO, Goldscheid N, Brüning T, RaulfHeimsoth M. Comparison of wheat and rye flour skin prick test solutions for diagnosis of baker's asthma. Allergy 2004;59:95-8.

21. van Kampen V, Merget R, Rabstein S, Sander I, Bruening T, Broding HC, Keller C, Muesken H, Overlack A, Schultze-Werninghaus G, Walusiak J, Raulf-Heimsoth M. Comparison of wheat and rye flour solutions for skin prick testing: a multi-centre study (Stad 1). Clin Exp Allergy 2009;39:1896-902.

22. De Zotti R, Bovenzi M, Negro C, Cirla A, Innocenti A, Lorusso A, Mariano A, Paggiaro PL, Talini D, Pisati G, Romano C, Sulotto F. Specific inhalation challenge with wheat flour in workers with suspected baker's asthma. Int Arch Occup Environ Health 1999;72: 335-7.

23. Letrán A, Palacín A, Barranco P, Salcedo G, Pascual C, Quirce S. Rye flour allergens: an emerging role in baker's asthma. Am J Ind Med 2008;51:324-8.

24. van Kampen V, Rabstein S, Sander I, Merget R, Brüning T, Broding HC, Keller C, Müsken H, Overlack A, Schultze-Werninghaus G, Walusiak J, Raulf-Heimsoth M. Prediction of challenge test results by flour-specific IgE and skin prick test in symptomatic bakers. Allergy 2008;63:897-902.

25. Beach J, Rowe BH, Blitz S, Crumley E, Hooton N, Russell K, Spooner C, Klassen T. Diagnosis and management of work-related asthma. Evid Rep Technol Assess (Summ) 2005;(129):1-8.

26. Quirce S, Fernández-Nieto M, Escudero C, Cuesta J, de Las Heras $\mathrm{M}$, Sastre J. Bronchial responsiveness to bakery-derived allergens is strongly dependent on specific skin sensitivity. Allergy 2006;61: 1202-8.

27. Quirce S, Lemière C, de Blay F, del Pozo V, Gerth Van Wijk R, Maestrelli P, Pauli G, Pignatti P, Raulf-Heimsoth M, Sastre J, Storaas T, Moscato G. Noninvasive methods for assessment of airway inflammation in occupational settings. Allergy 2010;65:445-58.

28. Barranco P, Fernández-Nieto M, del Pozo V, Sastre B, Larco JI, Quirce S. Nonasthmatic eosinophilic bronchitis in a baker caused by fungal alpha-amylase and wheat flour. J Investig Allergol Clin Immunol 2008;18:494-5.

29. Tatham AS, Shewry PR. Allergens to wheat and related cereals. Clin Exp Allergy 2008;38:1712-26.

30. Shewry PR, Tatham AS, Halford NG. The prolamins of the Triticeae. In: Shewry PR, Casey R, editors. Seed proteins. Dordrecht: Kluwer Academic Publishers; 1999. 35-78.

31. Pastorello EA, Farioli L, Conti A, Pravettoni V, Bonomi S, Iametti S, Fortunato D, Scibilia J, Bindslev-Jensen C, Ballmer-Weber B, Robino AM, Ortolani C. Wheat IgE-mediated food allergy in European patients: alpha-amylase inhibitors, lipid transfer proteins and lowmolecular-weight glutenins. Allergenic molecules recognized by double-blind, placebo-controlled food challenge. Int Arch Allergy Immunol 2007;144:10-22.

32. Salcedo G, Quirce S, Diaz-Perales A. Wheat allergens associated with Baker's asthma. J Investig Allergol Clin Immunol 2011;21:81-92.

33. Sander I, Raulf-Heimsoth M, Düser M, Flagge A, Czuppon AB, Baur $\mathrm{X}$. Differentiation between cosensitization and cross-reactivity in wheat flour and grass pollen-sensitized subjects. Int Arch Allergy Immunol 1997;112:378-85.

34. Weiss W, Huber G, Engel KH, Pethran A, Dunn MJ, Gooley AA, Görg A. Identification and characterization of wheat grain albumin/globulin allergens. Electrophoresis 1997;18:826-33.

35. Sander I, Flagge A, Merget R, Halder TM, Meyer HE, Baur X. Iden- 
tification of wheat flour allergens by means of 2-dimensional immunoblotting. J Allergy Clin Immunol 2001;107:907-13.

36. Sandiford CP, Tee RD, Taylor AJ. The role of cereal and fungal amylases in cereal flour hypersensitivity. Clin Exp Allergy 1994;24:549-57.

37. Kimoto M, Suzuki M, Komiyama N, Kunimoto A, Yamashita H, Hiemori M, Takahashi K, Tsuji H. Isolation and molecular cloning of a major wheat allergen, Tri a Bd 27K. Biosci Biotechnol Biochem 2009;73:85-92.

38. Palacin A, Quirce S, Sánchez-Monge R, Fernández-Nieto M, Varela J, Sastre J, Salcedo G. Allergy to kiwi in patients with baker's asthma: identification of potential cross-reactive allergens. Ann Allergy Asthma Immunol 2008;101:200-5.

39. Pahr S, Constantin C, Mari A, Scheiblhofer S, Thalhamer J, Ebner C, Vrtala S, Mittermann I, Valenta R. Molecular characterization of wheat allergens specifically recognized by patients suffering from wheat-induced respiratory allergy. Clin Exp Allergy 2012;42:597609.

40. Salcedo G, Sanchez-Monge R, Garcia-Casado G, Armentia A, Gomez L, Barber D. The cereal $\alpha$-amylase/trypsin inhibitor family associated with baker's asthma and food allergy. In: Mills ENC, Shewry PR, editors. Plant food allergens. Oxford: Blackwell Science; 2004. 70-86.

41. Carbonero P, Salcedo G, Sanchez-Monge R, Garcia-Maroto F, Royo J, Gomez L, Mena M, Medina J, Diaz I. A multigene family from cereals which encodes inhibitors of trypsin and heterologous $\alpha$ amylases. In: Aviles FX, editor. Innovations in proteases and their inhibitors. Berlin: Walter de Gruyter; 1993.333-48.

42. Oda Y, Matsunaga T, Fukuyama K, Miyazaki T, Morimoto T. Tertiary and quaternary structures of 0.19 alpha-amylase inhibitor from wheat kernel determined by X-ray analysis at $2.06 \mathrm{~A}$ resolution. Biochemistry 1997;36:13503-11.

43. Gomez L, Sanchez-Monge R, Garcia-Olmedo F, Salcedo G. Wheat tetrameric inhibitors of insect alpha-amylases: Alloploid heterosis at the molecular level. Proc Natl Acad Sci U S A 1989;86:3242-6.

44. Gutierrez C, Sanchez-Monge R, Gomez L, Ruiz-Tapiador M, Castañera P, Salcedo G. $\alpha$-Amylase activities of agricultural insect pests are specifically affected by different inhibitor preparations from wheat and barley endosperms. Plant Sci 1990;72:37-44.

45. Gutierrez C, Garcia-Casado G, Sanchez-Monge R, Gomez L, Castañera $P$, Salcedo $G$. The three inhibitor types from wheat endosperma are differentially active against $\alpha$-amylases of Lepidoptera pests. Entomol Exp Appl 1993;66:47-52.

46. Pfeil T, Schwabl U, Ulmer WT, König W. Western blot analysis of water-soluble wheat flour (Triticum vulgaris) allergens. Int Arch Allergy Appl Immunol 1990;91:224-31.

47. Gómez L, Martín E, Hernández D, Sánchez-Monge R, Barber D, del Pozo V, de Andrés B, Armentia A, Lahoz C, Salcedo G, Palomino $P$. Members of the alpha-amylase inhibitors family from wheat endosperm are major allergens associated with baker's asthma. FEBS Lett 1990;261:85-8.

48. Fränken J, Stephan U, Neuber K, Bujanowski-Weber J, Ulmer WT, König W. Characterization of allergenic components of rye and wheat flour (Secale, Triticum vulgaris) by western blot with sera of bakers: their effects on CD23 expression. Int Arch Allergy Appl Immunol 1991;96:76-83.

49. Sanchez-Monge R, Gomez L, Barber D, Lopez-Otin C, Armentia A, Salcedo G. Wheat and barley allergens associated with baker's asthma. Glycosylated subunits of the alpha-amylase-inhibitor family have enhanced IgE-binding capacity. Biochem J 1992;281:
401-5.

50. Sandiford CP, Tee RD, Newman-Taylor AJ. Identification of crossreacting wheat, rye, barley and soya flour allergens using sera from individuals with wheat-induced asthma. Clin Exp Allergy 1995;25: 340-9.

51. Amano M, Ogawa H, Kojima K, Kamidaira T, Suetsugu S, Yoshihama M, Satoh T, Samejima T, Matsumoto I. Identification of the major allergens in wheat flour responsible for baker's asthma. Biochem J 1998;330:1229-34.

52. Fränken J, Stephan U, Meyer HE, König W. Identification of alphaamylase inhibitor as a major allergen of wheat flour. Int Arch Allergy Immunol 1994;104:171-4.

53. Theobald K, Thiel H, Kallweit C, Ulmer W, König W. Detection of proteins in wheat flour extracts that bind human IgG, IgE, and mouse monoclonal antibodies. J Allergy Clin Immunol 1986;78: 470-7.

54. Armentia A, Sanchez-Monge R, Gomez L, Barber D, Salcedo G. In vivo allergenic activities of eleven purified members of a major allergen family from wheat and barley flour. Clin Exp Allergy 1993; 23:410-5.

55. García-Casado G, Armentia A, Sánchez-Monge R, Sánchez LM, Lopez-Otín C, Salcedo G. A major baker's asthma allergen from rye flour is considerably more active than its barley counterpart. FEBS Lett 1995;364:36-40.

56. García-Casado G, Armentia A, Sánchez-Monge R, Malpica JM, Salcedo G. Rye flour allergens associated with baker's asthma. Correlation between in vivo and in vitro activities and comparison with their wheat and barley homologues. Clin Exp Allergy 1996;26: 428-35.

57. Barber D, Sánchez-Monge R, Gómez L, Carpizo J, Armentia A, López-Otín C, Juan F, Salcedo G. A barley flour inhibitor of insect alpha-amylase is a major allergen associated with baker's asthma disease. FEBS Lett 1989;248:119-22.

58. Sánchez-Monge R, García-Casado G, López-Otín C, Armentia A, Salcedo G. Wheat flour peroxidase is a prominent allergen associated with baker's asthma. Clin Exp Allergy 1997;27:1130-7.

59. Yamashita H, Nanba Y, Onishi M, Kimoto M, Hiemori M, Tsuji H. Identification of a wheat allergen, Tri a Bd $36 \mathrm{~K}$, as a peroxidase. Biosci Biotechnol Biochem 2002;66:2487-90.

60. Kobrehel K, Wong JH, Balogh A, Kiss F, Yee BC, Buchanan BB. Specific reduction of wheat storage proteins by thioredoxin h. Plant Physiol 1992;99:919-24.

61. Weichel M, Glaser AG, Ballmer-Weber BK, Schmid-Grendelmeier P, Crameri R. Wheat and maize thioredoxins: a novel cross-reactive cereal allergen family related to baker's asthma. J Allergy Clin Immunol 2006;117:676-81.

62. Salcedo G, Sánchez-Monge R, Barber D, Díaz-Perales A. Plant nonspecific lipid transfer proteins: an interface between plant defence and human allergy. Biochim Biophys Acta 2007;1771:781-91.

63. Palacin A, Quirce S, Armentia A, Fernández-Nieto M, Pacios LF, Asensio T, Sastre J, Diaz-Perales A, Salcedo G. Wheat lipid transfer protein is a major allergen associated with baker's asthma. J Allergy Clin Immunol 2007;120:1132-8.

64. Palacin A, Varela J, Quirce S, del Pozo V, Tordesillas L, Barranco P, Fernandez-Nieto M, Sastre J, Diaz-Perales A, Salcedo G. Recombinant lipid transfer protein Tri a 14: a novel heat and proteolytic resistant tool for the diagnosis of baker's asthma. Clin Exp Allergy 2009;39:1267-76.

65. Enrique E, Ahrazem O, Bartra J, Latorre MD, Castelló JV, de Mateo 
JA, Montoya E, Malek T, Barber D, Salcedo G. Lipid transfer protein is involved in rhinoconjunctivitis and asthma produced by rice inhalation. J Allergy Clin Immunol 2005;116:926-8.

66. Constantin C, Quirce S, Grote M, Touraev A, Swoboda I, Stoecklinger A, Mari A, Thalhamer J, Heberle-Bors E, Valenta R. Molecular and immunological characterization of a wheat serine proteinase inhibitor as a novel allergen in baker's asthma. J Immunol 2008; 180:7451-60.

67. Constantin C, Quirce S, Poorafshar M, Touraev A, Niggemann B, Mari A, Ebner C, Akerström H, Heberle-Bors E, Nystrand M, Valenta R. Micro-arrayed wheat seed and grass pollen allergens for component-resolved diagnosis. Allergy 2009;64:1030-7.

68. Lehto M, Airaksinen L, Puustinen A, Tillander S, Hannula S, Nyman T, Toskala E, Alenius H, Lauerma A. Thaumatin-like protein and baker's respiratory allergy. Ann Allergy Asthma Immunol 2010;104:139-46.

69. Liu JJ, Sturrock R, Ekramoddoullah AK. The superfamily of thaumatin-like proteins: its origin, evolution, and expression towards biological function. Plant Cell Rep 2010;29:419-36.

70. Walsh BJ, Howden ME. A method for the detection of IgE binding sequences of allergens based on a modification of epitope mapping. J Immunol Methods 1989;121:275-80.

71. Sandiford CP, Tatham AS, Fido R, Welch JA, Jones MG, Tee RD, Shewry PR, Newman Taylor AJ. Identification of the major water/ salt insoluble wheat proteins involved in cereal hypersensitivity. Clin Exp Allergy 1997;27:1120-9.

72. Mittag D, Niggemann B, Sander I, Reese I, Fiedler EM, Worm M, Vieths S, Reese G. Immunoglobulin E-reactivity of wheat-allergic subjects (baker's asthma, food allergy, wheat-dependent, exerciseinduced anaphylaxis) to wheat protein fractions with different solubility and digestibility. Mol Nutr Food Res 2004;48:380-9.

73. Snégaroff J, Branlard G, Bouchez-Mahiout I, Laudet B, Tylichova M, Chardot T, Pecquet C, Choudat D, Raison-Peyron N, Vigan M, Kerre S, Laurière M. Recombinant proteins and peptides as tools for studying IgE reactivity with low-molecular-weight glutenin subunits in some wheat allergies. J Agric Food Chem 2007;55: 9837-45.

74. Bittner C, Grassau B, Frenzel K, Baur X. Identification of wheat gliadins as an allergen family related to baker's asthma. J Allergy Clin Immunol 2008;121:744-9.

75. Baur X, Sauer W, Weiss W. Baking additives as new allergens in baker's asthma. Respiration 1988;54:70-2.

76. Baur X, Fruhmann G, Haug B, Rasche B, Reiher W, Weiss W. Role of Aspergillus amylase in baker's asthma. Lancet 1986;1:43.

77. Sander I, Raulf-Heimsoth M, Siethoff C, Lohaus C, Meyer HE, Baur X. Allergy to Aspergillus-derived enzymes in the baking industry: identification of beta-xylosidase from Aspergillus niger as a new allergen (Asp n 14). J Allergy Clin Immunol 1998;102:256-64.

78. Quirce S, Cuevas M, Díez-Gómez M, Fernández-Rivas M, Hinojosa M, González R, Losada E. Respiratory allergy to Aspergillus-derived enzymes in bakers' asthma. J Allergy Clin Immunol 1992;90: 970-8.

79. Quirce S, Fernández-Nieto M, Bartolomé B, Bombín C, Cuevas M, Sastre J. Glucoamylase: another fungal enzyme associated with baker's asthma. Ann Allergy Asthma Immunol 2002;89:197-202.

80. Merget R, Sander I, Raulf-Heimsoth M, Baur X. Baker's asthma due to xylanase and cellulase without sensitization to alpha-amylase and only weak sensitization to flour. Int Arch Allergy Immunol
2001;124:502-5.

81. Quirce S, Polo F, Figueredo E, González R, Sastre J. Occupational asthma caused by soybean flour in bakers--differences with soybean-induced epidemic asthma. Clin Exp Allergy 2000;30:839-46.

82. Quirce S, Fernández-Nieto M, Polo F, Sastre J. Soybean trypsin inhibitor is an occupational inhalant allergen. J Allergy Clin Immunol 2002;109:178.

83. Lavaud F, Perdu D, Prévost A, Vallerand H, Cossart C, Passemard F. Baker's asthma related to soybean lecithin exposure. Allergy 1994; 49:159-62.

84. Campbell CP, Yates DH. Lupin allergy: a hidden killer at home, a menace at work; occupational disease due to lupin allergy. Clin Exp Allergy 2010;40:1467-72.

85. Belchi-Hernandez J, Mora-Gonzalez A, Iniesta-Perez J. Baker's asthma caused by Saccharomyces cerevisiae in dry powder form. J Allergy Clin Immunol 1996;97:131-4.

86. Valdivieso R, Moneo I, Pola J, Muñoz T, Zapata C, Hinojosa M, Losada E. Occupational asthma and contact urticaria caused by buckwheat flour. Ann Allergy 1989;63:149-52.

87. Vandenplas O, Vander Borght T, Delwiche JP. Occupational asthma caused by sunflower-seed dust. Allergy 1998;53:907-8.

88. Escudero C, Quirce S, Fernández-Nieto M, Miguel J, Cuesta J, Sastre J. Egg white proteins as inhalant allergens associated with baker's asthma. Allergy 2003;58:616-20.

89. Revsbech P, Dueholm M. Storage mite allergy among bakers. Allergy 1990;45:204-8.

90. Armentia A, Tapias J, Barber D, Martin J, de la Fuente R, Sanchez P, Salcedo G, Carreira J. Sensitization to the storage mite Lepidoglyphus destructor in wheat flour respiratory allergy. Ann Allergy 1992;68:398-403.

91. Lunn JA, Hughes DT. Pulmonary hypersensitivity to the grain weevil. Br J Ind Med 1967;24:158-61.

92. Armentia A, Lombardero M, Martínez C, Barber D, Vega JM, Callejo A. Occupational asthma due to grain pests Eurygaster and Ephestia. J Asthma 2004;41:99-107.

93. Bobolea I, Barranco P, Pastor-Vargas C, Iraola V, Vivanco F, Quirce S. Arginine kinase from the cellar spider (Holocnemus pluchei): a new asthma-causing allergen. Int Arch Allergy Immunol 2011;155: 180-6.

94. Klaustermeyer WB, Bardana EJ Jr, Hale FC. Pulmonary hypersensitivity to Alternaria and Aspergillus in baker's asthma. Clin Allergy 1977;7:227-33.

95. Vandenplas O. Occupational asthma: etiologies and risk factors. Allergy Asthma Immunol Res 2011;3:157-67.

96. Armentia A, Martin-Santos JM, Quintero A, Fernandez A, Barber D, Alonso E, Gil I. Bakers' asthma: prevalence and evaluation of immunotherapy with a wheat flour extract. Ann Allergy 1990;65:265-72.

97. Swaminathan S, Heddle RJ. Wheat flour immunotherapy in baker's asthma. Intern Med J 2007;37:663-4.

98. Cirla AM, Lorenzini RA, Cirla PE. Specific immunotherapy and relocation in occupational allergic bakers. G Ital Med Lav Ergon 2007;29:443-5.

99. Olivieri M, Biscardo CA, Turri S, Perbellini L. Omalizumab in persistent severe bakers' asthma. Allergy 2008;63:790-1.

100. Pérez Pimiento A, Bueso Fernández A, García Loria J, Rodríguez Cabreros MI, Mosquera MR, García Cubero A. Effect of omalizumab treatment in a baker with occupational asthma. J Investig Allergol Clin Immunol 2008;18:490-1. 